УДК 221.7:141.5

A.В. Усик,

науковий співробітник Інституту філософії імені Г.С. Сковороди НАН України

\title{
КУЛЬТУРА КИТАЮ В ДИСКУРСІ СВОБОДИ: КОНФУЦІЕВИЙ РИТУАЛ
}

«Досить, щоб слова виражали смисл»

Конфуиій

Тема свободи в історії західної філософії посідає край важливе місце. 3 найдавніших часів проблема свободи порушує безліч питань та провокує активні дискусії. І навіть сьогодні не можна однозначно твердити, що $€$ чітка й універсальна відповідь на питання, що означає це поняття у філософії. Ми навіть візьмемо на себе сміливість твердити, що ситуація щодо мультиверсного визначення свободи навряд чи зміниться в майбутньому.

Наразі лише край стисло, оскільки не це $є$ предметом головного аналізу цього нашого дослідження, простежимо загальні тенденції тлумачення свободи в історичній ретроспективі. Дуже коротко можна висловити таку тезу: в історії розвитку поняття свободи тлумачення iii як творчої особистісної свободи поступово витісняє поняття свободи людини від певних перепон (чи-то казуальності, чи-то примусу, чи-то долі). Так, західна стародавня філософія (Сократ, Платон) розмірковує насамперед про свободу в долі, про свободу від політичного деспотизму (Аристотель). Середньовічна філософії має провідною темою свободу від гріха. А ось вже Ренесанс несе із собою розуміння свободи як вільне розгортання людської особистості. Ще далі йдуть просвітники, виходячи з теми панування усемогутньої природної причинності та закономірності. Порушується питання про свободу як постулат морально-творчої відповідності сутності та їі розвитку (Кант, Шиллер, Ніцше, Шопенгауер та ін.). У Новий час в європейських країнах домінує ідея духа миру і трансцендентних цінностей. Новітні постмодерністські течії закликають твердити про свободу як плюралізм цінностей, де основою стає свобідна взаємодія, спілкування, розуміння будь-якого об’єкта. 
Докорінно інша ситуація з тлумаченням терміна «свобода» в китайській філософії. Прямо кажучи, тема свободи людини китайській філософії взагалі невідома. Ні, тобто свобода сама по собі була. Така, як їі мислити й сповідували давні китайці. Але, як відзначає у своєму інтерв'ю сучасній пресі В.Рибаков, сучасний російський сходознавець, «в Китаї, коли туди приплили європейські вчені книги, перекладачам довго довелося вигадувати ієрогліфічний термін для позначення поняття «свобода». Не було у мові такого слова! Просто анекдот: свобода чотири тисячоліття як була, а слова не було! Що, в Китаї не існувало гульби, стрілянини, не було розбійників? Були, але вони навіть не вигадали слова «свобода». Навіть розбійники знали слово «справедливість» і слово «повинність», а без слова «свобода» цілком обходилися. Спроби знайти свободі китайське ім'я були вельми складним. I так, і так намагалися - і все одно виходило не те. То «розбещеність», то «самодурство», то «свавілля», то «неповага»... Врешті-решт зійшлися на біномі «цзию». У сучасній науковій літературі воно, звісно, перекладається як свобода, але дослівно означає «сам із себе».

Отже, у сучасній китайській мові поняття «свобода» виражається через біном «цзи ю», де цзи означає «сам», а ю - «із». Таким чином, за словами відомого російського синолога Є.Торчинова, «цзи ю» за своєю внутрішньою формою означає «те, що виходить із самого себе», тобто із своєї власної природи. Тобто бути свобідним означає жити відповідно до власної природи, бути самим собою [1].

А що ж означає для носія китайської культури «бути собою»? Як саме визначає китайська філософія людську природу, людське єство?

Аналізуючи китайську філософську традицію доводиться погодитися із думкою сучасного філософа С.Козія, що загалом культура Китаю в дискурсі свободи $є$ конформістською: вона поєднує у собі дві несумісності - даосизм і конфуціанство. Даосизм проповідує діяння, що не суперечить природі речей, зумовленої причиннонаслідковими взаємодіями. Конфуціанство проповідує ритуал і ієрархічність соціальних відносин [2]. Конфуцій вважав, що ідеальний порядок може бути встановлений лише за допомогою «лі». «Лі»це принцип взаємної поваги. Це багатозначне слово. Воно позначає порядність, ввічливість, церемонію i, нарешті, ритуал - один з основних понять Конфуцієвої соціальної етики. Тут однозначно треба 
визначити для себе, щоб Конфуцієве розуміння свободи має насамперед не особистісне, а соціальне забарвлення. Ідеальним він вважає таке суспільство, де свобода існує, але не породжує конфліктів і несправедливості, тому що усі люди є високоморальними і поводять себе відповідно порядно до інших. Батьки мають бути добрими батьками, діти - слухняними дітьми, правителі мають вміти добре управляти, а громадяни мають бути гідними громадянами.

Ця ідея яскраво виражена в конфуціанському канонічному тексті «Да сюе» («Велике Вчення»): «Стародавні, бажаючи висвітлити добрі чесноти у Піднебесній, 3 початку впорядковували свою державу, бажаючи впорядкувати свою державу, вони впорядковували свої сім’ї, бажаючи впорядкувати свої сім'ї, вони само впорядковувалися, бажаючи само впорядкуватися, вони виправляли своє серце-розум, бажаючи виправити своє серце-розум, вони робили щирим своє життя, бажаючи зробити щирим своє життя, вони доводили знання до кінця; знання доводиться до кінця у визначенні речей-сутностей».

Зупинимося докладніше на первісному китайській традиції розумінню ритуалу. Китайський ритуал розвивався з найдавніших часів китайської цивілізації, а в VI-V ст. до н.е. дістав кінцевого оформлення та визнання одним з найвидатніших китайських мислителів у семантиці категорії «лі». Дотримання «лі»- це не лише встановлення послідовності визначених дій, і не лише найголовніша етична категорія Конфуцієвого мислення, а й особливий спосіб життя, різні боки якого знайшли упорядкування і в зовнішніх, i у внутрішніх проявах особистості через знання та виконання відповідних обставинам ритуальних дій. Ритуал та різноманітні другорядні доброчесності міцно переплетені та навіки зв'язані між собою в етиці Конфуція: китайський ритуал потребує не лише зовнішнього виконання, а й глибокого внутрішнього самозреченого почуття; виконувати конфуціанський ритуал, не володіючи комплексом моральних доброчесностей, неможливо.

Шлях до вдосконалення в розумінні сутності ритуалу проходить через «переборення самого себе», тобто через переборення індивідуальних властивостей, через повне підпорядкування моральноетичним вимогам еталону цзюнь-цзи. Цей шлях диктує виснажливу працю, пов'язану із самовдосконаленням, цілковиту самовідданість 
у виконанні службових обов'язків (адже “цзюнь-цзи”, як ми вже відзначали, - не лише ідеальна в моральному розумінні особистість, а й досконалий чиновник-адміністратор) та, крім того, розвиток глибокого духовного почуття, що межує з екстазом, під час виконання ритуально-обрядових дій, якими з усіх боків було оточене його життя.

У функції загального визначника способу соціальних взаємовідносин та внутрішнього стану людини ритуал у Конфуцієвому вченні виконує роль регулятора соціально-політичного життя держави. Мислитель визнає сучасний йому соціум як такий, що перебуває у стані глибокого занепаду та, жаліючи з цього приводу, звертається до найдавнішого періоду історії китайської цивілізації у надії знайти в минулому рятівний круг для суспільства, яке, на його думку, гине. У ті, “золоті” для людини китайської цивілізації, часи, коли у Піднебесній панувала гармонія, а Небо ще не було відокремленим від землі, і люди, які володіли безсмертям, могли без перешкод пересуватися із землі на небеса, ритуальні дії були нормою взаємовідносин між людьми та богами, а в соціально-історичному зрізі - способом самої соціалізації. Вони виконували функцію механізму приборкання ентропії і на соціальному, і на космічному рівнях. Розмірковуючи про рівень соціального й політичного ладу в сучасній йому державі, Конфуцій застосовує термін “дао” - 3 метою, напевно, підкреслити основний аспект свого вчення. Сенс його полягає в тому, що соціальний ідеал мислителя - “доброчесний муж” - здатний цілковито виявити свої досконалості саме у самовідданому виконанні службових обов'язків, кінцевою метою яким $€$ підтримання соціальної і політичної гармонії в Піднебесній.

Саме цей смисл Конфуцій вкладає в категорію “дао”, коли використовує іiі у широкому значенні і тим самим шукає засоби подолання означеної негативної суспільної ситуації. Відзначимо, що Конфуцій був високоосвіченою та культурною людиною свого історичного часу. Тривалі роки він займався вивченням стародавніх канонів, вдосконалюючи й шліфуючи свої знання. Він добре знав стародавню історію та культурну традицію Давнього Китаю, яка зароджувалась у ранні міфологічні часи і поступово розвивалась, ставала та, зрештою, визначила провідну інтенцію китайської ментальності. Конфуцію вдалося чітко усвідомити цю інтенцію, яка повертала назад, в “ідеальну” давнину, в “реальність пам'яті”. Він 
виявився таким дальнозорим та гнучким, що своєю діяльністю не лише не вчинив спробу змінити, якимось чином трансформувати загальну спрямованість китайської ментальності, а навпаки - усіма своїми силами намагався підтримати й розвинути їі в сучасному йому суспільстві. У своєму вченні він закріплює іманентну давньокитайській свідомості ретроградну спрямованість, більше того, ретельно відтворює іiі та деталізує різні можливі шляхи повернення до неї суспільством середини I тис. до н.е.

Ритуал був одним 3 найголовніших регулюючих інститутів давнини, до якої прагнула, як ми бачили раніше, духовна інтенція сучасника Конфуція. Ритуал, який за міфотворчих часів поєднував у собі гармонізуючу та світовпорядкувальну функцію, у Конфуцієвій філософії стає тим принциповим механізмом, який має перебороти сили хаосу у V ст. до н.е. - тільки вже не космічного, а соціального. Оскільки основною метою вчення Конфуція $є$ саме гармонізація соціальних відносин, то дотримання ритуальних норм має у ньому велике, якщо не сказати головне, значення. Конфуцій ретельно оточує внутрішній світ та зовнішні прояви людини різнорідними ритуальними обмеженнями, до того ж не входячи при цьому в суперечність із загальним духом китайської культури. Дотримання ритуальних традицій, на думку мислителя, мало поступово перебороти соціальну дисгармонію та стати гарантом ідеального порядку в Піднебесній. Однак цей план натрапляє на певні ускладнення: сучасник Конфуція не вбачає потреби в такому ретельному виконанні ритуальних церемоній, тобто цілком виправдано не бажає перетворювати своє життя на акт самопожертви заради встановлення ідеального соціального порядку. I має щодо цього свою аргументацію. Адже ритуальні норми старовини з часом спрощувались, деякі 3 них, які не мали життєво потрібного значення, взагалі забувалися i відкидалися традицією, що здається людині часів Конфуція досить закономірним результатом трансформації історичного часу.

Ставлення до ритуалу, який у міфотворчі часи виконував антиентропійну функцію, тобто влаштовував соціальну та космічну гармонію, з розвитком китайського суспільства та держави певним чином змінюється мірою виконання ним свого основного завдання, а саме - соціалізації стародавньої людини. Зрозуміло, що людина V ст. до н.е., яка на той час була підданою великої держави із, 
здавалося їй, визначеною системою політичної влади та чіткою структурою соціальних відносин вкладала дещо інший смисл у виконання церемоніальних обрядів. Але Конфуцій, який став духовно вищим за свою цивілізацію, із сумом визнає, що сучасне йому суспільство перебуває в глибокому занепаді, що міра його ентропії така значна, що сягає рівня, порівняльного зі стародавнім хаосом. У зв'язку з цим мислитель реально оцінює нагальну потребу негайного повернення в мораль і звичаї сучасного йому суспільства колишньої значущості ритуальних традицій. Як справжній носій традиційної китайської ментальності з іiі “реальністю пам’яті” він жалкує, що люди “вже не ті”, і що дуже складно довести їм кончу потребу таких дій.

Перед Конфуцієм постає завдання: 3 метою гармонізування суспільства та держави загалом, докласти зусиль 3 виправлення моральності самої особистості як елемента цього суспільства, бо лише “нова”, досконала людина буде здатною перетворити соціум, членом якого вона є. Мислитель розробляє комплекс моральних норм, беручи при цьому за еталон моральність мудрих правителів давнини, а як очікуваний ідеал - теоретичну модель досконалої людини “цзюнь-цзи”.

Отже, основною метою своєї діяльності Конфуцій вбачає гармонізацію суспільства в цілому, а провідним засобом іiі досягнення застосування ритуальних норм як методу боротьби із соціальною ентропією. Мислитель розуміє, що досягти цього неможливо без застосування інституту морально досконалих особистостей “цзюньцзи”, а основним способом їхнього впливу на суспільство визначає метод особистого впливу. Іншими словами, засобами досягнення мети впорядкування сучасної йому суспільної кризи Вчитель покладає наразі два провідних принципи, а саме - ритуалізації та моралізації членів соціуму, що потребує у вдосконаленні. Ці два принципи в доктрині мислителя є цілком невід'ємними один від одного, саме тому з тексту “Лунь юй” зазвичай неможливо визначити першочи другорядність тих чи інших нормативів: ритуальні церемонії та найвищі моральні доброчесності є однаково першорядними в якості засобів боротьби із соціальною ентропією.

3 огляду на це зрозуміло, що “лі” посідатиме неподільно монопольне положення в ідеальному житті Конфуцієвого доброчесного 
мужа, відкидаючи на другий план усі інші моральні доброчесності (які, як ми побачимо, неспроможні існувати, та навіть виникнути без ретельного виконання ритуальних дій). Тому запропоновані варіанти перекладу цієї категорії давньокитайської філософії - як-то “ритуал”, “обряд” - висвітлюють, на нашу думку, лише один бік того багатофункціонального комплексу різнобічних проявів життя, на які має вплив “лі” у тлумаченні китайського Вчителя. Отже, передавання змістовного значення китайського ієрогліфа “лі” словами “ритуал”, “обряд”, безперечно, позбавляє вагомої частини його внутрішнього змісту - але про це дещо пізніше.

Наразі розглянемо, на яких принципах грунтується вибірковість ритуальних норм, здійснена Конфуцієм. "Із призначень ритуалу важливішою є гармонія... Але й гармонія може бути застосована не завжди. Якщо знають гармонію, не обмежуючи іiі ритуалом, вона не може втілюватись у життя" $[3,57]$. Отже, гармонія - потенційний стан порядку та рівноваги в Піднебесній, але проявлятися вона може лише втіленою в ритуальні норми. Якщо застосувати цей загальний принцип у площині соціальній, то його можна інтерпретувати наступним чином: 3 одного боку, гармонічна особистість “цзюнь-цзи” не в змозі якимось чином впливати на звичаї суспільства 3 метою їх покращання (а це, як ми пам’ятаємо, є іiі основним призначенням, згідно з вченням Конфуція), якщо не дотримуватиметься визначених ритуальних норм. 3 іншого боку, внутрішній потенціал своєї моралі “цзюнь-цзи” повинен проявити завдяки ритуалу. У першому випадку виконання ритуалу, поряд з володінням комплексом моральних доброчесностей, є неодмінними компонентами становлення особистості як доброчесного мужа, тобто між ритуалом та мораллю існує паралельний, горизонтальний зв'язок як між рівнозначними складовими процесу формування ідеальної людини. У другому випадку ритуал є другим (не за значенням, як-то другорядний, а саме за послідовністю) ланцюгом морального становлення “цзюнь-цзи”, до того ж його функція полягає не так у формуванні, як у втіленні в життя особистих моральних якостей доброчесного мужа. У будь-якому разі зрозуміло, що ритуал і мораль, навіть якщо їхня семантика не синонімічна, не відокремлюються один від одного, бо мораль не здатна проявитися (або сформуватися) без ритуалу, а без моралі ритуалу немає що втілювати у життя. 
Однак Конфуцій не поспішає з остаточним визначенням першорядності ритуалу чи моралі: в “Лунь юй” знаходимо висловлювання, які підтверджують то перше, то друге припущення. “До чого ритуали, якщо, будучи людиною, не проявляти людяності?” [3, 63]. Із цього можна припустити, що “людяність” у даному разі мислитель тлумачить як невід'ємну властивість людини, яку вона повинна втілити в суспільне життя, роблячи тим самим особистий внесок у гармонізацію соціуму. Однак якщо дехто, “будучи людиною”, не володіє “жень”, та, звісно, не має потреби їі “проявляти”, то ритуал цій людині справді не потрібний, бо він є лише механізмом втілення моралі. Ритуал у цьому разі тлумачиться не як друга (за послідовністю) побудова (оскільки немає першої, тобто моралі), а як паралельна та рівнозначна моралі структура. Звісно, оскільки тут мораль та ритуал $є$ взаємозалежними, а один елемент (мораль) відсутній, то природно, що в ритуалі, справді, не має сенсу. А ось і підтвердження другого припущення: у відповідь учню Конфуцій твердить: “Вторинним $\epsilon$ те, коли розфарбовують біле”. “І ритуал $є$ вторинним?”, знов допитується учень. “Хто мене розуміє, так це ти!”- радіє вчитель $[3,64]$. Отже, образне порівняння ритуалу з хитромудрим візерунком на білому полотнищі (тобто, якщо розглядати це в етикосоціальному розумінні, то на тлі моралі) підкреслює характер його функціонального призначення, а саме - втілення в життя моральних властивостей особи завдяки особливому переліку ритуальних дій.

Ритуал здатний впливати на рівень розвитку тих чи інших моральних властивостей: “Поважливість без ритуалу втомлює, а обережність без нього веде до боягузтва; при сміливості без ритуалу піднімають смуту, від прямоти без ритуалу стають нестерпними" $[3,91]$. Цей афоризм засвідчує, що мораль і ритуал є не відокремленими, а скоріше паралельними структурами Конфуцієвої доктрини: вони міцно взаємопов'язані, а їхні прояви принципово впливають один на одного. "Бути людяним - це означає перебороти себе та вдатися до ритуалу” $[3,113]$. Тобто, як і “жень”, “лі” не є вродженим природі людини, тому що, за мислителем, для його досягнення потрібно “перебороти себе", тобто перебороти свій характер i, як ми вже знаємо, саму індивідуальність людини через підпорядкування загальній соціалізації. Лише завдяки вивченню та втіленню в життя ритуальних настанов “цзюнь-цзи” може посісти відповідне йому 
місце в соціальній ієрархії: “Хто не вивчає ритуал, тому не знайти свого місця" [3, 147].

Отже, категорія “лі” у Конфуцієвій етиці посідає центральне місце. Поряд з моральними доброчесностями ритуал сприяє формуванню характеру доброчесного мужа i, крім того, втілює його позитивні внутрішні властивості в життя соціуму. Завдяки цьому він виступає в ролі безпосереднього механізму гармонізації соціально-політичних відносин у державі та виконує антиентропійну функцію в різних сферах життєдіяльності Піднебесної.

Ритуальні норми “лі”, які зародились ще в міфотворчі часи, пройшли до сучасності Конфуція тривалий шлях. Сфера їх впливу була надзвичайно широкою: починаючи від сакральних жертвопринесень Небу та закінчуючи нормами шлюбно-сімейних відносин. Велика кількість стародавніх обрядів та церемоній у середині I тис. до н.е. вийшла 3 активного використання, лишаючись у пам'яті народу лише у вигляді згадок у стародавніх канонах чи творах усної народної творчості. Значна кількість ритуалів зберегла свою загальну сутність, але трансформувала деякі деталі. Політичний занепад китайської держави в період Чжаньго, сучасний Конфуцію, крах інституту єдиної централізованої влади, криваві князівські міжусобиці, головною метою яких був захват центральної влади в Китаї, призвели до викривлення та змішання ритуальних палацових нормативів, які $з$ найдавніших часів до того моменту лишались непорушними та були показниками збереження субординації між чиновниками різних рівнів. Проводирі бунтівних кланів, намагаючись підняти свій авторитет, посягали на ті ритуальні церемонії (жертвопринесення, музика, танці), які споконвіку виконувались виключно в імператорському палаці та були символами імператорської влади. Ці дії були проявом великого свавілля і не лише підривали основи центральної державної влади, а й мали грандіозні наслідки в соціально-етичному полі китайської культури. Міцні устої ритуальних традицій були розхитані, а разом 3 ними - і звичаї та порядок у народі, бо китайські ритуали завжди виконували функцію гармонізуючого фактору. У зв'язку із занепадом культурних традицій соціум мав гостру потребу в новій, розрахованій на виправлення моральних пороків, етичній доктрині, яка сприяла б реставрації та відродженню традиційних позитивних 
моральних устоїв та ритуальних традицій (саме в реставрації, а не у введенні нових, бо вектор прагнення китайської культури незмінно спрямований у минуле). Саме тому певну “ретроградність" Конфуція слід визнати як адекватну відповідь на критичну ситуацію в китайській культурі.

Однак навіть зважаючи на це слід відзначити, що доктрина мислителя щодо ритуалу пройнята немалою часткою догматизму та консерватизму. Конфуцій категорично відкидає зміни та спрощення обрядових дій, які існували в ті часи в китайському суспільстві, та наполягає на буквальному відродженні традицій ритуального минулого: “Відповідно ритуалу государя потрібно вітати на вході до зали. Але тепер вітають після того, як він уже увійшов до зали. Це є проявом зарозумілості. І хоч я йду проти всіх, але вітаю його, стоячи на вході до зали” [3,96]; “Цзи-гун хотів покласти край звичаю приносити в жертву барана в перший день місяця. Вчитель сказав: “Ти турбуєшся про барана, а я турбуюсь про ритуал” $[3,66]$. Звісно, що введення (спроба відтворення) таких суворих ритуальних норм суперечило характеру вже закріплених в історичній свідомості людей спрощень. Навіть найближчий учень Конфуція пропонує змінити застарілий ритуал жертвопринесення, однак мислитель категорично проти цього: головним фактором упорядкування звичаїв у Піднебесній він вперто вважає безперечне дотримання стародавніх ритуальних церемоній.

Сам Конфуцій також намагався ретельно виконувати ритуальні обряди в усіх можливих проявах своєї діяльності. У “Лунь юй” знаходимо опис виконання ним ритуальних дій, якому навіть присвячений окремий розділ. У ньому знайшли місце відомості про ритуальний одяг, харчування - у буденні дні та в дні посту, а також опис кількох ритуальних обрядів у виконанні Конфуція. "Коли він держав скіпетр князя, то, здавалося, згинався весь, наче не міг втримати. Він підіймав його, наче в поклоні, опускав додолу, немов збираючись щось передати, з трепетливим виглядом та наче зміненим обличчям, йшов обережно, як по перекладині, дрібними кроками" $[3,102]$; “Коли князь наказував йому прийняти гостей, він наче і в обличчі мінився, і ноги у нього наче підгиналися. Він вклонявся по бокам сановникам, які стояли поряд з ним, підіймаючи до грудей складені руки, при цьому його одяг не збирався у зборки, та поспішав 
уперед, простягнувши руки, немов крила. А коли гості відходили, обов'язково доповідав: “Гості вже більше не обертаються” [3, 101-102].

Отже, розглянувши методи реставрації ритуальних традицій та спосіб взаємозв'язку між основними домінантами етичної доктрини Конфуція - ритуалом та мораллю - як абстрактними етичними категоріями, звернемося до проблеми практичного втілення ритуальних норм, тобто до питання про те, в який же спосіб обрядові традиції впливають на типову етичну характеристику “цзюнь-цзи” як безпосереднього їх носія.

Китайським ритуалом просякнуті всі прояви життєдіяльності “цзюнь-цзи”. Щодо способів їх застосування конфуціанські “лі” виходять далеко за межі того ритуалу, який зароджувався за архаїчних часів: вони охоплюють майже суцільно всю сферу так званої культурної поведінки. Внутрішньо “лі” також значно відрізняються від комплексу вже відомих Китаю того часу церемоній. Емоційно-змістовно Конфуцієві “лі" наближуються до архаїчних ритуальних дій, виконанню яких властиві велике внутрішнє напруження та активне співпереживання розвиткові ритуального сценарію. “Лi” у тлумаченні Вчителя накладають суворі обмеження на вчинки людини - таким чином, що індивід дістає можливість здійснювати лише ті дії, які входять до ритуальних норм. Крім того “лі" контролюють слова та мову доброчесного мужа.

Обмежується і сфера контакту з навколишнім світом, оскільки “лі” нормують не лише діяльність самого індивіду (тобто те, що “виходить” безпосередньо від нього), а й ті прояви його оточення, які так чи інакше здатні впливати на людину. Іншими словами те, що “входить” у людину, що вона здатна сприймати органами чуття, те, що може викликати в ній відповідну реакцію: “На те, що не відповідає ритуалу, не можна дивитися; те, що не відповідає ритуалу, не можна слухати; те, що не відповідає ритуалу, не можна говорити; те, що не відповідає ритуалу, не можна робити” [3, 113], ось якою є Конфуцієва настанова.

Крім суворого контролю за словами, діями та обмеження контактів з навколишнім світом (як-то “не дивитися”, “не слухати”), Конфуцієвий “цзюнь-цзи” повинен обмежувати навіть сферу своїх знань та освіти: “доброчесний муж, оволодіваючи вченістю, може межу не перейти, якщо буде себе стримувати правилами ритуалу” [3, 84]. 
Приділяється значна увага врегулюванню обсягу знань, якими має володіти “цзюнь-цзи”. Про цю особливість свідчить те, що наведена сентенція повторюється, як особливо важлива, і в іншому розділі “Лунь юй”. Крім того, схожі висловлювання у збірці взагалі непоодинокі - натрапляємо ще на кілька сентенцій, в яких йдеться про кончу потребу обмежувати й контролювати якість і обсяг знань, котрі отримує людина.

Більше того, Конфуцій навіть визначає перелік книг, які (і жодні інші) слід використовувати як джерела освіти. Серед них - кілька давніх збірок, у кожній з яких міститься вузько галузева інформація. Так, в одній - з історії Стародавнього Китаю (“Шу цзин”), в іншій про пісні та гімни з народного життя, перекази про міфічних героїв та мудрих легендарних правителів (“Ши цзин”), у третій - різнорідні ритуали та обряди - від сімейно-побутових традицій до урочистих ритуалів імператорських жертвопринесень Небу (“Лі цзи”) тощо.

Згідно 3 даними стародавніх переказів та хронік є підстава вважати, що мислитель особисто коментував та редагував матеріали деяких давніх канонів, серед яких з найбільшою певністю можна назвати такі, як “Ши цзин” та “Лі цзи”. Пізніше, коли конфуціанство стало державною ідеологією Китаю, ці джерела, а також і сам “Лунь юй”, були канонізовані та протягом майже двох тисячоліть входили у програму обов'язкової освіти. "Хто не вивчає Пісень, не може нічого сказати... Хто не вивчає ритуалів, тому не знайти свого місця" [3, 147], - підкреслює Конфуцій, а сам про себе твердить: “Я надихаюсь Піснями, шукаю опори в ритуалах та завершую музикою” $[3,93]$.

Таким чином, хоча освіченість поціновувалася як невід'ємна властивість доброчесного мужа, іiі рівень підлягав суворій регламентації: обсяг знань контролювався, визначався перелік дозволених джерел навчання. Адже і характер, і спосіб отримання знань мали, за доктриною Конфуція, відповідати нормам ритуалу.

Отже, функції Конфуцієвого “лі” аж ніяк не обмежуються регламентацією зовнішніх, соціальних проявів особистості. Одним з важливих, якщо не найважливішим призначенням ритуалу є ретельний контроль саме за внутрішнім станом людини, що провадиться, зокрема, через вибірковість музичних ритмів (а музика, зрозуміло, справді здатна значно впливати на настрій людини), а також вимоги 
глибокого емоційного співчуття будь-яким ритуальним маніпуляціям.

Коротко підсумуємо. Як ми бачили, “лі” у тлумаченні Конфуція приховує в собі величезний семантичний матеріал. Як абстрактна категорія, “лі” невідмежне від “жень”. Обидва принципи приховують у собі могутній гармонізуючий потенціал: “жень” - у сфері моралі та світовідношенні людини, “лі” - як головний фактор, спрямований на регулювання взаємовідносин між людьми, тобто як засіб соціальної “упорядкованості”. Особливістю проявів “лі” та “жень” є їхня міцна взаємозалежність: суспільство потребує порядку, тобто ритуалізації, але вона може відбутися лише після того, як втілиться в життя ідеальний образ високоморальної особи “цзюнь-цзи”, тобто посередництвом суцільної моралізації суспільства. Ідеальна мораль та моральність здається Конфуцію внутрішнім потенціалом та фундаментом здорового соціуму. А механізмом їх втілення мислитель вважає “ритуал”, якому з моменту його зародження у китайській культурі притаманна місія глобальної антиентропійної функції. У практичному плані, тобто щодо реального впливу на людську особистість, “лі” проявляється в ретельно укомплектованому переліку ритуальних норм та настанов, які показують моральне обличчя доброчесного мужа. Загалом, “лі” накладає жорстку регламентацію на внутрішній світ людини та спосіб іiі соціальних проявів через: втілення ритуальних церемоній, які просякають усі сфери життєдіяльності людини; суворий контроль за мовою і способом висловлювання своїх думок; вибірковість знань (освіти); ритуалізацію музики; суворе підпорядкування емоційно-чуттєвого стану характеру обрядового акту.

\section{ЛІТЕРАТУРА}

1. Торчинов Е.А. Пути филосфии Востока и Запада: познание запредельного. - СПб. : Азбука-классика, 2007. - С. 60.

2. Козий С. Дао - Лао Цзы, Конфуций и Кант в дискурсе Свободы.

3. Луньюй. Изречения // Конфуций. Я верю в древность. - М. : Республика, 1995. 
Усик А.В. Культура Китаю в дискурсі свободи: Конфуиієвий ритуал.

Тема свободи $\epsilon$ наскрізною для західної філософської традиції. Питання іiі тлумачення бентежило філософський дискурс Заходу з часів античності, находило свої варіанти у Середньовіччі, трансформувалося в Нові часи. У сучасному вигляді, але в мультиверсному розумінні, представлено постмодерністською філософською традицією. Автор статті порушує питання розуміння поняття «свобода» східною філософською традицією на прикладі раннього конфуціанства. Відзначається, що розуміння теми свободи у філософії у Давньому Китаю докорінно відрізняється від західного. Пояснюється, що терміна «свобода» в давній китайській традиції власне не існувало. Це поняття розумілося філософськими течіями Китаю як само собою зрозуміле, а щодо конфуціанської традиції воно розчинялось у головних для неї питаннях - про природу людину та способи гідної соціальної взаємодії.

Ключові слова: свобода, дискурс свободи, конфуціанство, вчення Конфуція, китайська філософія.

Usyk A. China's Culture in the Discourse of Freedom: The Confucian Ritual.

The theme of freedom is through the western philosophical tradition. The question of her confinement was confused by the philosophical discourse of the West from the time of antiquity, found its variants in the Middle Ages, transformed into New Times. In the modern form, but in a multiversive sense, is represented by a postmodern philosophical tradition. The author of the article raises the question of understanding the concept of "freedom" by the Eastern philosophical tradition on the example of early Confucianism. It is noted that understanding the theme of freedom in philosophy in Ancient China is radically different from the West. It is explained that the term "freedom" in the ancient Chinese tradition actually did not fall asleep. This concept was understood by the philosophical currents of China as a matter of course, and as for the Confucian tradition, it was dissolved in the main questions for her about the nature of man and the ways of decent social interaction.

Key words: freedom, discourse of freedom, Confucianism, Confucius doctrine, Chinese philosophy. 